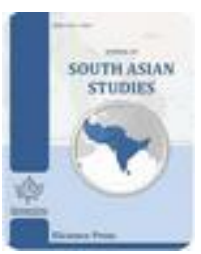

Available Online at EScience Press

Journal of South Asian Studies

ISSN: 2307-4000 (Online), 2308-7846 (Print)

https://esciencepress.net/journals/JSAS

\title{
INTER-CASTE MARRIAGE IN CONFLICT SETTINGS: WAR, DISPLACEMENT, AND SOCIAL CONDITIONS IN CROSS-CASTE KINSHIP FORMATIONS IN JAFFNA, NORTHERN SRILANKA
}

\author{
Thanges Paramsothy \\ Department of South Asian Studies, Cornell University, Rockefeller Hall, Ithaca, New York 14853-2502, USA.
}

*Corresponding Author Email: thangesanp@gmail.com

\section{A B S T R A C T}

The war and subsequent displacements changed the social and spatial practices around caste, which resulted in an increase in inter-caste marriages, which had been taboo before. This unintentional rebellion was mounted to the very core of caste through these inter-caste marriages. However, the new caste practices and performances that now revolved around these new inter-caste kin networks continued to reproduce old hierarchies, even as it created space for change. This study highlights how various determining factors such as repeated displacement of families, the close geographic proximity resulting from inevitable cross-caste interactions, love and intimate relationship, the safeguard different caste individuals extended to each other during the periods of crisis and emergency and socioeconomic advancements have together contributed to the steady growth of inter-caste interaction and marriages and have overridden caste taboos. This study mainly focuses on two areas namely Pungudutīvu and Mallākam in Jaffna, Northern Sri Lanka, where 116 inter-caste marriages were recorded and three were taken for a detailed case study.

Keywords: inter-caste marriage, kinship formation, war, displacement, Jaffna Tamil.

\section{INTRODUCTION}

Marriages took place within the same caste groups (caste endogamy). Inter-caste marriages (caste exogamy) rarely took place here. After the LTTE (Liberation Tigers of Tamil Eelam) came to power, marriages between different caste groups increased. The LTTE leader Prabakaran (Karaiyāri) married a Vellālarii caste woman who belongs to Pungudutivvuiii.

The Vellālar woman who mentioned this about the LTTE leader, Prabaharan's marriage, also said that Prabaharan's father in law refused to accept the marriage especially as Prabaharan belonged to the Karaiyārcaste. However, later he was proud to call Prabaharan his son-in-law and celebrated the conjugal relationship when he became popular and was the leader of the de-facto Tamil Eelam state in Sri Lanka. Here, the caste issue in the conjugal relationship did not last long and slowly disappeared. After hearing a couple of similar and contradictory stories, I wanted to know further on this subject of inter-caste marriage. I, therefore, have recorded 116 inter-caste marriages in
Pungudutīvu and Mallākam iv in Jaffna peninsula. Out of 116 inter-caste marriages, 108 marriages took place following the escalation of civil war particularly after the year 1990. Three inter-caste marriages were chosen for the detailed ethnographic case study. Such inter-caste marriages have also created a space where the divisions of families in terms of caste differences have been reinforced and led to a scenario of separation between families from newly wedded couples.

There are a substantial number of inter-caste marriages as a result of the increasing interaction of different caste groups in conflict settings. Inter-caste marriage is usually opposed in both traditional and contemporary caste-divided Jaffna Tamil society. It is viewed as a form of social intrusion threatening the fundamental social order, including caste 'purity' and the reproduction of caste, negotiation of dowry, caste-based kinship formation, and the extended family unit or family alliances. However, responding to the emerging everyday needs of people, marriages (including intercaste marriage) in war-affected Jaffna play multiple roles 
in terms of economic security, material status, transnational migration, and (cross-caste) kinship formation. This article, using ethnographic case study methods, highlights the multiple reasons for the increasing number of inter-caste marriages in the time of armed conflict and conflict-induced displacements in Jaffna. It considers how such inter-caste marriages were instrumental in cross-caste kinship formations with certain social conditions imposed on such marital alliances and extended family unions and illustrates how such conditions ensure caste continuity and segregation.

\section{INTER-CASTE LOVE MARRIAGE VS. ARRANGED MARRIAGE IN JAFFNA}

An arranged marriage is the socially accepted marriage practice in Jaffna where a person is expected to marry a partner within the same caste group with the consensus of their parents and close relatives. It can be applied to all caste groups who are positioned either on the top, the middle, or the bottom of the caste ladder. Caste is the fundamental principle for such an arranged marriage (pechchuttirumanam) where all caste groups irrespective of their status carefully consider the origin of caste before the marriage negotiation (sampantappechchu). Arranged marriage (caste endogamy) is viewed as a form of the social system repeatedly ensures the fundamental social order, caste purity/reproduction of caste, negotiation of dowry, caste-based kinship formations, the extended family unit/family alliances (David 1973a; Banks 1960 and Yalman 1967; McGilvray1973, 1982).

Arranged marriage is an important institution where Jaffna Tamils openly discuss caste identity. Each party is very keen to know about the caste background of the potential partner. A good example for this is the matrimonial advertisement columns in Tamil and English newspapers, where the caste of the potential bride or groom is mentioned in order to find a match within his or her own caste group. The dominant Veḷālar caste does not hesitate much in pointing out their caste status, whereas other caste groups usually avoid indicating their caste name in the advertisements. The term sāti (caste) is usually avoided in advertisements as discussing or writing this in public is not appreciated. When an advertisement is displayed in a newspaper, the words kulam (clan) and samūkam (community) are used instead of the wordsāti. In addition, the terms enkkadaākkal (our people - indicating both the same ethnic group and the same caste group) and enkkadasontakkārar (our relatives - indicating the same caste group) are often used among Jaffna Tamils, both in ordinary conversations and marriage negotiations. The process of arranged marriage usually begins only after verifying caste status of the potential partner. Arranged marriage in traditional Jaffna society took place between close relatives, who knew each other before the marriage alliance. The marriage in this context was mostly known as an alliance between cross-cousins in Dravidian South Asian society (David 1973a). As Banks (1960: 70) indicates, sontakkārar castes are not a strictly endogamous closed system, new marriages do occur between previously unrelated wards, and old alliances are discontinued. The arranged marriages are not necessarily between relatives. If the potential marriage partner is from the same caste, then the marriage negotiation takes place and new kinship begins within the same caste group. Caste continuously remains one of the traditional and fundamental institutions through which new kinship is developed and family alliances ensured. Such arranged marriages continue to support the caste divisions and its elements despite the war and displacement-related dynamics in the caste domain of Jaffna.

As a result of the dispersed nature of Tamils in the contemporary context, the village or ward-based locality and agents of traditional arranged marriages have changed in relation to the migratory and transnational settings of Tamils (Sidharthan 2009; Sidharthan and Van Hear 2012). However, despite this change, the fundamental principle of arranged marriages where caste is carefully considered is still widely in practice. Eńkadaākkaḷ/eñkadasontakkārar refers to the same caste group regardless of the locality of the family and marraākkalare outsiders or another caste. Marraākkal in all ritual relations is treated as outsiders (veḷiyāḷ/pirattiyār).

Banks record that 'thousands of Jaffna people have lived most of their adult lives in other parts of the world. When such men return to Jaffna, they readily fall back into the local social system (1960: 75).' These men return to find spouses within their own caste group with a hefty dowry. Outside exposure hasn't changed the attitudes about same caste marriages, which are quite prevalent among a substantial number of asylum migrants who fled the country following the escalation of civil war since the 1980s. Arranged marriages 
between individuals residing both abroad and at home are developed to recreate and/or reunite the dispersed caste and kin-based community in a transnational setting rather than a broader Tamil community perspective. The patterns of caste endogamy include a method of finding a potential marriage partner, negotiation of dowry, locality of marriage and its functions which to a great extent have changed due to the transnational nature of Tamil community (Sidharthan and Van Hear 2012). However, the institution of caste in such an arranged marriage plays a vital role through which marriages are arranged, new family alliances are formed, and conjugal relationships maintained.

Arranged marriage within the same caste is not the only form of marriage among Jaffna Tamils, there have also been inter-caste marriages, widely known as 'love marriagev'(kātaltirumanam/kātalkaliyānam) in Jaffna. When the same caste couple falls in love and marries, it usually ends with an arranged marriage due to their similar caste status. The term "love marriage" is usually reserved for inter-caste marriages, which are usually opposed by family members. The arranged marriages are increasingly challenged by the younger generation. This contemporary pattern of inter-caste marriage weakens the constructed caste boundaries and the notion of 'caste purity'. Regardless of the challenges, a substantial number of inter-caste marriages have been taking place in Jaffna. This has made such marriages a social reality and is a consequence of conflict and rapid social changes; youths' behavioural and attitude changes and the choice of an individual. Even though it is not viewed as a serious issue in contemporary Jaffna, intercaste marriage is not openly welcomed or celebrated. Both dominant and oppressed castes oppose intermarriages, but rarely exert force to separate the newly wedded couple. In some instances, both families of newly wedded couple refuse to accept the marriage and shun the couple. It is very rare for both families to accept the inter-caste couple immediately after their marriage. There are some examples of such marriages accepted by both families. This creates a scenario where kinship is formed and developed across the different caste groups. It is a notable difference in contemporary Jaffna society in comparison to the pre-war Jaffna.

WAR, DISPLACEMENT AND INTER-CASTE MARRIAGE Caste oriented geographical boundaries and segregation were not strictly followed in the backdrop of displacements due to lack of space and meagre resources. The congregated people of all walks of life suddenly found themselves in a limited space that had to be shared, hence becoming neighbours. People irrespective of caste differences helped each other in order to access the basic needs of food, shelter etc. It is this scenario that was instrumental in the increased inter-caste marriages thereby breaking caste boundaries. The other factor for inter-caste marriages apart from the close-knit residential status was the urgent need for the marital status of young people. Most married youths escaped potential threats, arrests, and harassment from both the "open custody vi" of the LTTE and the Sri Lankan army at this tumultuous time. Having a spouse and children was seen as being encumbered with responsibility and hence unlikely to get involved in war-related activities or the LTTE armed movement. This, however, did not mean safety for all married persons from potential threats. There are a number of missing husbands and disappearances in the midst of war and post-war. A number of marriages took place during the final stage of the war both in the LTTE and army controlled areas, apparently as a safeguard mechanism against forcible recruitment, arbitrary arrest and torture.

According to the data that I collected in both field sites in Jaffna, 116 inter-caste marriages had taken place from 1960 to 2015. Out of this, 61 marriages took place during 2000-2009. Similar growth in inter-caste marriage was seen in the post-war years of 2010-2015 (see table1). Chart 1 . shows the steadily increasing intercaste marriage since the 1990s. Many of these marriages took place to while away from home. The prolonged displacement created a space for the younger generation to develop contacts with their potential life-partners of different regions and caste groups. Sharp growth in inter-caste marriages continues even in the postwar/displacement period.

Table 1. Inter-caste Marriage in Conflict Settings.

\begin{tabular}{lr}
\hline Year & Number of Inter-caste Marriages \\
\hline $1960-1969$ & 1 \\
$1970-1979$ & 1 \\
$1980-1989$ & 6 \\
$1990-1999$ & 15 \\
$2000-2009$ & 61 \\
$2010-2015$ & 32 \\
Total & 116 \\
\hline
\end{tabular}




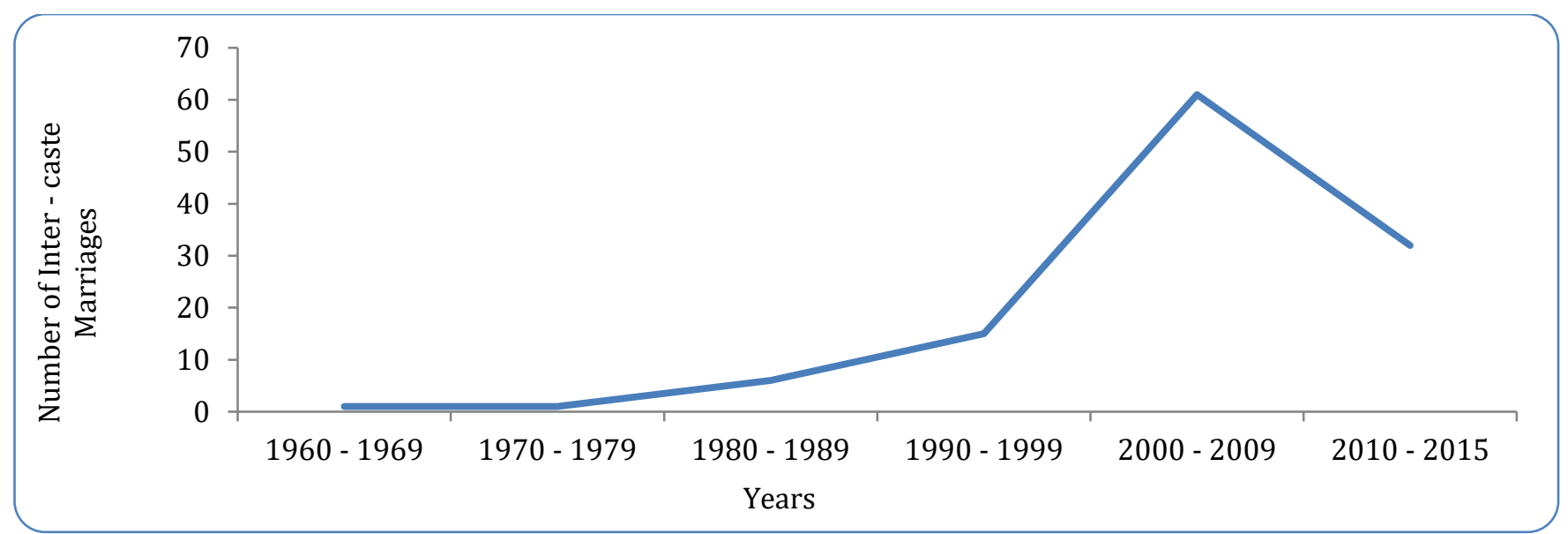

Chart 1. Inter-caste Marriages in Conflict Settings.

The highest number of inter-caste marriages took place between 2005 and 2010. This was the period when the civil war between the LTTE and the Sri Lankan forces reached its peak before the LTTE was defeated in 2009. People traditionally lived in their wards where each group separately arranged their residential space(David 1973b). These spatial arrangements have strictly been continued for many centuries in Jaffna. The repeated displacements during the ethnic conflict and the movements of families from one ward to another and one region to another have significantly affected the traditional spatial organization of castes and inter-caste relations. In Pungudutivu, for example, the majority of Vellāalars who displaced in 1991 did not return home. They settled in new places such as Jaffna, Colombo and abroad using their socioeconomic networks and capital, which they already established before the ethnic conflict began. McDowell (1996: 278), who researched on Tamil asylum migrants in Switzerland, indicates that 'Puñgudutīvāns (people of Punggudutīvu) are, in a sense, a model of Tamil asylum migrants in Switzerland enjoying greater relative success in socio-economic domains.' A substantial number of stone houses, which were built and occupied by the Vellālarars in Pungudutīvu are now completely abandoned due to their displacement and dislocation within the country and abroad. The traditional geographical boundaries in relation to caste-based differences are challenged due to such population displacements and their choice of residence in new places. People got used to being mobile by rooting and uprooting repeatedly in the time of crisis. However, in some instances, even during the displacement and relocation, such caste-based geographical boundaries are reproduced and solidified, particularly in the long-term IDP camps all over Jaffna peninsulavii. The displacements of families have played a role in the steady growth of inter-caste marriage in Jaffna.

\section{PARVATHY'S STORY}

Parvathy's husband worked as a manager in a tavern in Nainātīvuviii. He was transferred to Punggudutīvu in 1994. During that time Parvathy's younger brother also got a job in Pungudutivu hospital. This was a very tense period, during which the LTTE used to fight against the Sri Lankan army. In 1997, there was a cross-firing between the LTTE and the Sri Lankan army. There were a few people scattered in Pungudutivvu. It created tension among people and prevented them from moving outside their homes. After the incident, the Sri Lankan forces rounded up the places where the armed fight took place. They were searching for the injured/dead bodies of the LTTE. As they could not find the bodies, they went to Pungudutivu hospital on the suspicion that the bodies could have been taken there. Parvathy's brother, a young man was on duty at that time, the Sri Lankan army asked him about the dead bodies. As the bodies were not brought to the hospital, he said: "enakkutteriyātu sir" (I don't know sir) in Tamil. He did not understand Sinhala, which was spoken by the Sri Lankan army. At that time the doctor was also there, however they took away only her brother insisting that the bodies had in fact been brought to the hospital. The army took her brother to Madattuveḷi (an area in Pungudutivvu). They stripped him and buried him in a miry pit up to his chest and told him that he would be released only if he could bring the 
bodies and warned him that he would be shot dead if he failed to do so.

Parvathy's husband could not go to the place, as he is a man. If he went there, he could face a similar punishment. Parvathy got to know this from her husband. She immediately got a boat from Nainativu to Pungudutivu with her mother and three children. One of her children was a newly born infant. Parvathy went to the place with the baby and claimed her brother was her husband. There was an army commander who eventually released him on the basis that he returns every week to the army camp for signing. Tamil women during the period of violence used to claim that their male relatives and sometimes their close neighbours were their husbands to prevent potential arrest and harassment. This would create sympathy that a family depends on him. There is a pre-judgment that the family man is a responsible person who will not get involved in unnecessary issues (tevaiyilāppirachchinai) particularly against Sri Lankan forces by associating themselves with the LTTE.

As Parvathy used to visit with her brother and infant to the army camp every week, she could not go back to her place of origin (Nainātīvu)and leave her brother alone. She decided to stay in Pungudutivu. There were a number of stone houses without people. Parvathy comes from a Paraiyarix caste background and came across a Veḷālar family living alongside in ward 2, Pungudutīvu. The very few families living in the area lived away from the Veḷạlar family. The Vellālar woman was with two children and requested Parvathy to stay next to her where there was an abandoned house of a Vellālarfamily who has been living in Canada. Parvathy occupied the house with the permission of the absentee landlord. Parvathy and her family had been living in the same house since July 1997. The Veḷālar and Paraiyar became intimate neighbours mutually supporting each other during the crisis. Parvathy recalled an incident as follows:

One day in the absence of my husband and younger brother, I was standing by the veranda, when an army person walked through the back of my home exposing his genital. I panicked and hurried to my neighbour's home while calling her and pretending not to have seen him. From that day onwards, we were very careful. If dogs barked, we were alerted to army arrival, so we immediately come out of the house and start talking to each other. This was how we avoided potential threats. We continued this strategy until other families, following the peace talks resettled in the ward in 2002. I continued my relationships with other Veḷālar families as well until my daughter got married to a Veḷālar man.

There were very few families remaining in Pungudutivvu supporting each other during the time of crisis. After the Sri Lankan forces captured the entire Jaffna peninsula in 1996, some of the Pungudutīvu inhabitants who were internally displaced returned home. Parvathy remained in the same place as her Veḷālar neighbours.

After Parvathy's elder daughter completed her advanced level education, Parvathy fixed an arranged marriage for her in 2013. The groom was from the same caste and living in Canada. However, the arrangements had to be halted when to Parvathy's surprise her daughter eloped with the Vellālar neighbour. The groom's elder brother committed suicide after the inter-caste marriage. The rumour was that he poisoned himself to death because of his friends' merciless teasing about his brother's inter-caste marriage. It was said that they had teased him as to whether he would follow suit and possibly find a bride from the Pallar caste. This inter-caste marriage between the Vellạlar and the Paraiyar created a boundary. The previous interactions came to an abrupt halt causing a rift between the two families. The deeply submerged caste segregation came to the forefront with all the conventional arguments such as the division of families and breaking of age-old traditions used to defend caste endogamy.

The Vellālar family who had been very close to Parvathy's family was upset with the elopement and stopped all interactions with them. Even after the marriage, other Vellạlars continued to interact with Parvathy's family, however, she could feel the difference in attitude and heard their discussions; 'because we allowed her into our neighbourhood only she found a Veḷālarmāppiḷlai (bridegroom) and bought a Veḷālar land.' Although the inter-caste interactions can be seen as part of the social reality in multi-caste villages in Jaffna, the caste-based domination and exclusion have been systematically articulated by indirect means. This deeply rooted caste attitude comes to the surface when love and inter-caste marriages take place in society. This is also because inter-caste marriage significantly breaks the caste hierarchical difference, hence the so-called 'upper caste' Veḷạlars and others who believe that they 
are higher in the caste ladder attempt to ensure such differences by avoiding relations with oppressed caste families and partners.

Once Parvathy heard the discriminatory talk of her neighbours about her and her family, she reduced her interactions with them. She avoids visiting their homes. Her daughter, who visited her husband's home and the houses of other Veḷāilar neighbours before the marriage, is not welcome anymore. Her husband visits his family and gives money to his mother every month. He never takes his wife with him and Parvathy explained why:

I have no problem accommodating my daughter and her husband (son-in-law). They visit me regularly and have food at my home, even last night they came for dinner. However, the Veḷaalạ family is not in a position to invite their daughterin-law, due to fear of rejection by their relatives and neighbours. This rejection hurts my daughter. Yesterday, after dinner, my son-in-law left my daughter behind and visited his home. My daughter was unhappy, even though she doesn't discuss anything about this with me, as a woman and mother I can feel her sadness and pain.

Parvathy's story indicates that the social relationship between oppressed castes and the Vellālar has certain limitations. In the contemporary context, there is no explicit barrier to visiting homes of different caste groups and even sharing food between oppressed and dominant castes. The relations that the dominant castes have with the oppressed castes significantly changed after the inter-caste marriages. Inter-caste marriages particularly affect social relations, status, and hierarchical order. The status and hierarchical differences openly play a role in this context where the code of behaviour changes and the attitude of neighbours vary.

A number of contradictory issues come together in this case study. This case illustrates the points of political violence, displacement, residential arrangements and an inter-caste marriage of a couple. The community, irrespective of caste background, lived close to each other during the armed conflict and displacement. This was especially possible in Pungudutivu and other islands that saw a mass exodus of the dominant Vellạlars. The occupation by oppressed caste groups of abandoned Veḷāalar houses became relatively easy in these islands where the chance of Vella was minimal. This was because these people are well settled in other parts of Sri Lanka and abroad and the other deterrent factors include lack of infrastructure, water resources, education, and employment. Some Vellạalar families abroad do not oppose the occupation of their house, as the property gets maintained and deters potential theft. All of these reasons played a role in creating new patterns of the spatial organization of caste. The new and conflict-induced spatial arrangement of different caste groups not only changes the caste-based spatial organization (David 1973b) but also the inter-caste relations, including of inter-caste marriages in contemporary Jaffna.

\section{ANUSKA'S STORY}

Anuska is the third eldest daughter in her family. She belongs to the Nalavar caste (toddy tappers). She has two elder brothers, one younger brother, and a younger sister. She had been living in Mallākam with her parents and her siblings. Her family moved to the Vanni region ${ }^{x}$ following the mass exodus of Jaffna's inhabitants in $1995^{x i}$. While a substantial number of people returned to Jaffna following the capture of the region by the Sri Lankan forces, others remained in Vanni. Anuska's family also joined the people moving to Vanni. One of her brothers migrated to the UK as an asylum seeker during their internal displacement. None of the members in Anuska's family continues their castebased occupation. Her father and brothers are all professional motor mechanics and run a mechanic shop. No one could identify their caste origin based on their job.

Anuska and her family moved to a place in the Vanni where their neighbours were predominantly Veḷạlạ. A Vellāalar caste family who migrated from Point Pedro also lived nearby. Anuska used to go to their house to collect water, as there was no well ${ }^{x i i}$ in the place where Anuska's family lived. The frequent visits to access water created a relationship with the Vellâalar family. The son of the Vellạalar family, Kunalan and Anuskafell in love with each other. Kunalan's family tried to break them up and shifted to another place in the Vanni. However, the love affair continued even after they moved to a new place. During the peace talks ${ }^{\text {xiii }}$ (20022006), Anuska's family moved to their place of origin, Mallākam and Kunalan's family returned to their home in Point Petro. Kunalan against his family's wishes got married to Anuska in 2003. Kunalan's family did not know Anuska's actual caste so he told his family that 
Anuska belonged to the Kōviyarxiv caste, which is only a little lower than the Vellălars. Kunalan's family eventually agreed to accept their marriage as they were satisfied, she was not from so-called "lower caste."

Anushka was accepted in their home. She cooked food for all the family members. Everyone except Kunalan's mother ate the food prepared by Anuska. Kunalan's mother avoided eating the food, as it was cooked by a person of an inferior caste. She also avoided eating the food as revenge against her son's marriage. Kunalan's brother arranged a home for the newly wedded couple near his home in Point Petro. Anuska eventually became pregnant and delivered a baby boy after moving to their rental house. For the first time, Anuska's family visited her home to see the new-born baby. The neighbours, who knew Anuska's parents and their caste background, told this to Kunalan's family. Kunalan's siblings and parents were disappointed when they learned the truth. This created a dispute between Kunalan and his siblings. His brother who had arranged the rental house asked him to leave the house immediately. Anuska, Kunalan and their infant moved to Mallākam where Anuska's parents live. However, Kunalan continues to take his son for visits to his parents' and siblings' place while the notable absentee is his wife, Anuska. Kunalan's parents and siblings made a condition that if Anuska needs to have a relationship with them, she should leave her parents and siblings. If she continues having a relationship with them, their people (their caste groups) will get to know her caste background. This would then affect their relationship with their relatives. In some instances, the dominant caste families avoid a public relationship with the "lower caste" in-laws to avoid snubs from their sontakkārar (kin groups or closed relatives).

Anuska, after thirteen years of marriage, regrets marrying outside her caste and believes that a person should marry within the same caste group (sontattikkaseiyavenum). Inter-caste marriages according to her experience generate a continuous rift within family members. Initially, her son was confused as to why his mother avoided visits to his father's relatives. He now realizes the reason why. In Anuska's case, inter-caste marriage led to social taboo and separation from in-laws' family as she comes from an "unacceptable lower caste", whereas if she had been only a slightly "lower caste" (Kōviyar)she would have been accepted. Anuska's in-laws attempted to purify their caste identity by shunning her and disassociating themselves from her and her family members, soon after they got to know her actual caste background.

According to this case study, inter-caste love marriage becomes a social taboo and/or separation from parent's family, when such marriage occurs between individuals of "upper" and "lower" caste groups whereas the love marriage between the same caste individuals and/or similar caste groups (between Vellāla ar and Koviyar) is not much opposed by the couple's families. When Anuska was identified as Koviyar, she was treated as an insider by her husband's siblings and relatives. Soon after her caste origin is known as Nalavar she was treated as an outsider and a potential threat to their relations with their close relatives and caste groups. The family members of Anuska's husband attempted to purify their caste identity by keeping her away from their family members and disassociating their relationship with her and her family members.

\section{KUMARY'S STORY}

Kumary belongs to the Vellạlar caste and her hometown in Jaffna is called Alaveddy. She has two sons and two daughters. Kumary lost her husband to serious illness and she has been living with her children in her dowry house. She and her four children went to a wedding in Vanni in 2006. During this period the Norwegian government-sponsored peace talks between the LTTE and the government of Sri Lanka came to an end resulting in the closure of the main road connecting Vanni with Jaffna. Kumary along with her children were trapped in Vanni, which was under LTTE control. The final phase of the Eelam warkv commenced and Kumary and her children faced repeated displacements during the armed conflict. During the displacement Kumary lost her elder son to shelling and her 20 year old daughter was missing. The other son was injured and is now unable to walk properly.

On May 2009, Kumary and her younger daughter and injured son moved to the Sri Lankan forces run Ānanta Kumārasamy DIP camp in Vavuñiyā. This was where she discovered her missing daughter and also learnt that her daughter got married to a man from Pungudutīvu who was also their neighbour in Vanni. She discovered that they got married to avoid scrutiny and persecution from the forces, who were trying to weed out the LTTE cadres who had mingled with civilians. To avoid such issues, many other unmarried 
youths also hurriedly got married. Kumar did not oppose their decision, as they needed to protect themselves during the crisis. They eventually had a registered marriage with Kumary's blessing, even though Kumary knew her son-in-law was from Paraiyar caste. Kumary claimed to be Veḷạlar but did not make an issue in the first place because of the circumstances that made marriage a necessity. She stated, "I lost my son in the armed conflict, I am not willing to lose my daughter to caste differences."

Kumary's family covered the truth from their neighbours and relatives. They claim he is of the Vellâalar caste to avoid getting shunned. Kumary's close relatives in London have promised to sponsor her sonin-law to migrate to London. She believes that her relatives have offered to help him in the belief that he is from their caste. However, if they discover his real caste they are bound to stop help and interactions.

Kumary also mentioned that her relatives had shunned their own children who had married partners from other castes. Kumary's family refrains from interacting with the son-in-law's family to remove possibilities of identifying his caste. It is important to keep his caste a top secret if he is to migrate to the UK and help improve the family finances. It is believed that Kumary's son-inlaw is now identified as a Veḷạlar man by her relatives in the homeland and abroad. The imitation of 'upper caste status' gradually demolishes the ascribed status of caste known as primordial identity given by birth. The conventional interpretation of caste as an unchanging identity and hierarchical reality in terms of the notion of 'pure' and 'impure' in Dumont's (1970)terms is questioned here. Caste identity over a period of time for socio-economic and political reasons has changed. Interpreting the notion of a single caste group without mixing different castes in the formation of a caste community is highly problematic, as we have seen in this case study. Mixing different caste groups and pretending to be a particular (usually "upper") caste has been continuing in the formation of single caste group in Jaffna.

Different individuals and families, based on their socioeconomic and ritual circumstances, call themselves Vellâlar and claim that they belong to that caste group. In the course of time, they intermarry with the Veḷạlạar families and further strengthen their Vellālar identity. The Vellālars became a majority in Jaffna in the 1950s by intermarrying with caste groups who are slightly lower than their caste as recorded by Arasaratnam (1981). Sivathamby (2000) calls this a mega caste formation. He means that sub-divisions in each caste group slowly disappeared and it gradually became a single mega caste group. Kumary's case shows that the intermarriages in contemporary Jaffna society go beyond similar caste groups. Caste, particularly the Vellạlar, becomes highly mixed with different caste groups. The contemporary reality of 'Vellạalarization'xvi is not necessarily the sub-divisions within Vellạlar morphing with Vellạlar caste group. But it is the different caste groups marrying into Veḷạlar caste and achieving socio-economic and educational mobility. The assimilation of different caste groups into a single Vellạlar caste does not ensure the annihilation of caste taboo or hierarchies. It reproduces such caste hierarchical differences by making and unmaking boundaries after such assimilation. Hence, the status of different castes has been consistently constructed in relation to their association and interaction after their marriage in which those who are known as so-called "lower caste" are then identified with or known as socalled "high caste." It may also occur vice versa.

\section{CONCLUDING REMARKS}

Interactions and the formation of kinship across different castes are seen as relative concepts rather than freely operative between caste groups. Both parties in inter-caste marriages may accept the alliance if the caste status is only slightly lower whereas if the alliance involves castes that are significantly lower, it is likely to be a rocky alliance. For example, love marriages between the Veḷạlar and the Kōviyar are often accepted by both bride and bridegroom families. Marriage between Veḷạlar and Paraiyar, as we have seen in Parvathy's case, is not easily accepted by the dominant caste, Veḷ̂ạalar, or it might be accepted but with a lot of secrecy shrouding the alliance. However, there are a number of factors that not only increase inter-caste marriages but also bridge it. These factors include better socio-economic status, educational mobility, migration to affluent countries, repeated internal displacements during the conflict, mutual support during crisis and geographical proximity from displacement.

There are increasing numbers of inter-caste marriages in Jaffna and diaspora localities resulting in a substantial number of mixed caste groups in the Tamil 
population. The repeated displacements of families, the close geographic proximity resulting from inevitable cross-caste interactions during such displacements, intimate relationship, the safeguard different caste individuals extended to each other during periods of crisis and emergency have together contributed to the steady growth of inter-caste marriages and mixed caste population. The inter-caste marriages in the recent history of Jaffna society, questions the notion of 'caste purity'. The growing number of inter-caste marriages, the rapid growth of the mixed caste population, consent of one or both families have defied the fundamental character of caste and its purity in Jaffna.

These inter-caste marriages have also led to kinship formations across castes with some conditions imposed on conjugal relationships by blood and extended relatives. Such social conditions repeatedly ensure the continuation of the social order premised on castebased hierarchical differences and interactions and caste-related symbolic and material boundaries, though authors, scholars and social activists like Ambedkarxvii (1936) are of the view that caste exogamy, by subverting the caste boundaries present in the community, will gradually annihilate the institution of caste. Inter-caste marriage, therefore, doesn't necessarily imply that there is an acceptance of equality among the two caste groups/individuals/families who are so joined. All it means is that various other determining factors have over-ridden caste taboos, relations, hierarchies and reproduction in Tamil society. The increasing number of inter-caste marriages has also produced substantial mixed caste populations in contemporary Jaffna. Hence, the so-called notion of "caste purity" in Jaffna is highly challengeable. Yet, such "caste purity" is reproduced by both concealments of actual caste identity and enforcement of conditions in such inter-caste marriages and family alliances.

\section{ACKNOWLEDGEMENT}

I am very grateful to anonymous reviewers for reading an earlier version of this paper and providing their valuable feedback and comments. I take this opportunity to thank Francesca Bremner for providing insightful suggestions and comments for enhancing the value of this paper.

\section{REFERENCE}

Ambedkar, B. R. (1936). Annihilation of Caste, A Speech
Prepared for the annual conference of the JATPAT-TodakMandal of Lahore.

Arasaratnam, S. (1981). Social History of a Dominant Caste Society: The Vellalar of North Ceylon (Sri Lanka) in the $18^{\text {th }}$ Century. Indian Economic and Social History Review, xviii (3 and 4): 377-391.

Banks, M. (1960). Caste in Jaffna. In E. R. Leach, (ed.), Aspects of Caste in South India, Ceylon and North West Pakistan. Cambridge University Press, Cambridge, pp. 61-77.

David, K. (1973a). Until Marriage Do Us Part: A Cultural Account of Jaffna Tamil Categories for Kinsman, Man, 8(4): 521-535.

David, K. (1973b). Spatial Organization and Normative Schemes in Jaffna, Northern Sri Lanka. Modern Ceylon Studies, 4(1\&2): 21-52.

Dumont, L. (1970). Homo Hierarchicus: The Caste System and Its Implications. Chicago: The University of Chicago Press.

Hellmann-Rajanayagam, D. (1993). Jaffna Social System: Continuity and Change Under Condition of War, International Asienforum,24(3-4): 251-281.

Jeeweshwara, B. (2015). Caste and Nation-Building: Construction of Vellalah Identity in Jaffna. University of Gothenburg: School of Global Studies.

McDowell, C. (1996). A Tamil Asylum Diaspora: Sri Lankan Migration, Settlement and Politics in Switzerland. Oxford: Berhahn Books.

McGilvray, Dennis. B. (1982). MukkuvarVannimai: Tamil Caste and Matriclan Ideology in Batticaloa, Sri Lanka. In Dennis B. McGilvray, Caste Ideology and Interaction. Cambridge: Cambridge University Press, pp. 34-97.

McGilvray, Dennis. B. (1973). Caste and Matriclan Structure in Eastern Sri Lanka: A Preliminary Report on Fieldwork in Akkaraippattu, Modern Ceylon Studies, 4:5-20.

Raghavan, M. D. (1967). Tamil Culture in Ceylon: A General Introduction. Colombo: Kalai Nilaim Ltd.

Raghavan, M. D. (1953). Sociology of Jaffna: The Nalavar and the Koviyar.Tamil Culture, 2(3): 139-150.

Sidharthan, Maunaguru. (2009). Brides as Bridges? Movements, Actors, Documents and Anticipation in Constructing Tamilness. In R. Cheran (ed), Pathways of Dissent: Tamil Nationalism in Sri Lanka. United Kingdom: Sage Publication.

Sidharthan, Maunaguru \& Van Hear, Nicholas. (2014). 
Transnational Marriage in Conflict Settings: War, Dispersal and Marriage among Sri Lankan Tamils. In Katharine Charsley (ed), Transnational Marriage: New Perspectives from Europe and Beyond. United Kingdom: Rutledge.

Sivathamby, K. (2007). Divine Presence and/or Social prominence: An inquiry into the Social Role of the Places of Worship Jaffna Tamil Society. In K. Sivathamby, (ed.) Sri Lankan Tamil Society, and Politics. Chennai: New Century Book House, pp. 24-56.

Sivathamby, K. (2000). Jaffna: Society, Culture and
Ideology. Colombo: Kumaran Book House.

Srinivas, M. N. 1952.Religion and Society among the Coorgs of South India. London: Asia Publishing House.

UTHR(J). (1995). Exodus from Jaffna, Special Report No.6, $\quad$ Retrieved from http://www.uthr.org/SpecialReports/spreport6.h tm, Last Accessed: 29th October 2016.

Yalman, Nur. (1971). Under the Bo Tree: Studies in Caste, Kinship, and Marriage in the Interior of Ceylon. Berkeley: University of California Press.

i The Karaiyār is a fishing caste group in Jaffna who dominated the LTTE movement in order to fight for an independent Tamil homeland in the north and the east of Sri Lanka (see Hellman-Rajanayagam 1993 for further details).

ii The Vellālar is so-called "upper caste" in Jaffna. They were known as agriculturalists and landlords. They became numerically high and enjoyed the monopoly power over social, economic, political and ritual domains in Tamil dominated northern Sri Lanka (see Arasaratnam 1981; Jeeweshwara 2015 for further details)

iii Pungudutivu is a small island situated in the southwest of the Jaffna peninsula, Sri Lanka. It is 11.2 square kilometres in extent and 28 kilometres away from the centre of the Jaffna town. This island is divided into twelve wards and each was densely populated at one point of time. Its population was 20,000 before the Sri Lankan army captured this island. Upon the army capturing Pungudutivu in the year 1991, about 19,500 moved away from their village. In 1995, following the capture of Jaffna by the Sri Lankan army, people started to resettle in Pungudutivu. Approximately 3,000 people came back and resettled. The remaining 16,500 people who had abandoned Pungudutivu in the year 1991, moved to areas adjoining the Jaffna town and to other regions in Sri Lanka as well as to foreign countries. According to the census taken in January 2016, currently there are only a bare 4,000 people living in Pungudutivu.

iv Mallākam is a village situated towards the northern part of Jaffna along the side of Kānkesanturai (KKS) main road, under the administrative division of Vali North, Teḷippalai divisional secretariat.As of January 2016, the total population of Mallākamwas 6,753. It also includes the IDPs (Internally Displaced Persons) who live in four IDP camps in Mallākam.

v Different names are used for "inter-caste love marriage" in Tamil language in Jaffna. Virumpichcheitatirumaṇam (marriage according to the couple's wish), odichcheitatirumanam (marriage by eloping) and kātaltirumanam (love marriage) are some common names used by the Jaffna inhabitants.

vi Tamil people in the LTTE and army areas were closely monitored. They could not easily move out of the region. Those who wanted to move out of the district were required to get a pass. There were two pass systems in operation. They were the LTTEpass and the Sri Lankan army pass. Due to the high security and enforcement of pass systems for travelling from one region to another within the country, the places such as Jaffna and Vanni where Tamils predominantly lived were called "open prison/open custody".

vii Information pertaining to the caste composition of the people who live in the 32 IDP camps was collected in order to understand the correlation between landownership and caste in 2016. Surprisingly, certain caste groups, rather than a mixture of different caste groups, are predominantly present in all these IDP camps. Of the 32 IDP camps located in the Tellippalai, Uduvil, Sandilippāi, Kōppāi, Nallūr, Karavețty and Point Pedro divisional secretariats (DS divisions), the inhabitants of 25 camps predominantly belong to three oppressed caste groups namely Nalavar(toddy tappers), Pallar (agricultural labourers/toddy tappers) and Paraiyar (funeral drummers/cleaners). The remaining 6 IDP camps in the Point Pedro DS division only consist of Karaiyār(fishermen). One can observe that the re-territorialisation of old caste boundaries in entirely new war and displacementrelated residential settings in Jaffna.

viii Nainātīvu is an island located in Jaffna peninsula. This island is well known for its multi-cultural religious activities. Buddhists and Hindus do regularly visit this island in order to worship a Buddhist temple known as nākavikāri and Hindu temple called nainainākapoosaniamman. 
ix Paraiyar is one of the five oppressed castes in Jaffna. Their traditional caste-based occupation was funeral drummers and scavengers. They too played drums particularly in non-agamic Hindu temples.

x Vanni is a region, which covers Mannār, Vavuniyā, Mullaittīvu and Kilinochchi districts in northern part of Sri Lanka. It was particularly the Mullaittīvu and Kilinochchi districts from which people were displaced during the Jaffna exodus in 1995. These two districts at that time were completely controlled by the LTTE.

xi On $30^{\text {th }}$ October 1995, over half a million men, women and children fled their homes in Jaffna, due to the order of the LTTE to evacuate their homes within twenty four hours while the Sri Lankan forces advanced to capture the LTTE controlled areas in Jaffna (see UTHR(J) 1995, special report no.6 for further details)

xii The ground water is the main source of water in Jaffna and Vanni regions. Wells are constructed with cement and stone in order to block sand from falling into the well. Most of the stone houses in Jaffna have wells from which they draw water for drinking, bathing and other domestic purposes. The well water is also used for home gardening and agricultural purposes.

xiii The Norwegian government sponsored ceasefire agreement between the LTTE and the government of Sri Lanka is called as Memorandum of Understanding. This ceasefire agreement began in 2002 and came to an end in 2006.2002 to 2006 in the history of armed conflict of Sri Lanka is known as period of peace talks.

xiv Koviyars were traditionally known as domestic servants to the Vellāalars. They were not treated as 'untouchable'. Their position is slightly lower than the Veḷalăar in Jaffna caste hierarchical order (see Raghavan $(1953,1967)$ for further detail).

xv The war for a separate Tamil homeland (Tamil Eelam) in the north and the east of Sri Lanka is called Eelam war. The Eelam war, which commenced following the murder of 13 Sri Lankan soldiers in Jaffna and the consequent anti-Tamil riots (known as 1983 communal riots in Sri Lanka) elsewhere in the country, are divided into four different phases. The final phase of the Eelam War started after the peace talks sponsored by the Norwegian government came to an end in 2009.

xvi The concept of Vellāạarisation ranges from adapting or imitating the constructed customs, habits, and rites of dominant Vellālar caste to pretending or identifying themselves as Veḷāalar in society. Sivathamby (2007), using the Srinivas' (1952:30)concept of Sanskritization, illustrates how the deities, modes of worship, and status of temples have been transformed in relation to the agamic tradition. Changing the name of the deities, temples, and methods of worship are some examples of these transformations taking place at village levels in Jaffna peninsula.

xvii 'Annihilation of Caste' is the title of a speech prepared by B. R. Ambedkar for the annual conference of the JAT-PATTodakMandal of Lahore in 1936. However, the conference was cancelled by the reception committee on the ground that the views expressed in the speech would be unbearable to the conference. Much later, this undelivered speech and the AmbedkarGandhi debate on caste issues were edited as a book by Anand (2016).

Publisher's note: EScience Press remains neutral with regard to jurisdictional claims in published maps and institutional affiliations.

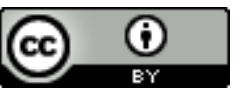

Open Access This article is licensed under a Creative Commons Attribution 4.0 International License, which permits use, sharing, adaptation, distribution and reproduction in any medium or format, as long as you give appropriate credit to the original author(s) and the source, provide a link to the Creative Commons license and indicate if changes were made. The images or other third-party material in this article are included in the article's Creative Commons license, unless indicated otherwise in a credit line to the material. If material is not included in the article's Creative Commons license and your intended use is not permitted by statutory regulation or exceeds the permitted use, you will need to obtain permission directly from the copyright holder. To view a copy of this license, visit http://creativecommons.org/licenses/by/4.0/.

(C) The Author(s) 2019. 